Vol. $15, n^{\circ} 2 \mid 2011$

Varia

\title{
Clive Emsley, Hard Men - Violence in England since
}

1750

London, Hambledon and London, 2005, ISBN 1-85285-408-1.

\section{Manuel Eisner}

\section{(2) OpenEdition}

\section{Journals}

Electronic version

URL: https://journals.openedition.org/chs/1310

DOI: $10.4000 /$ chs. 1310

ISSN: 1663-4837

Publisher

Librairie Droz

Printed version

Date of publication: 1 December 2011

Number of pages: 163-164

ISSN: $1422-0857$

\section{Electronic reference}

Manuel Eisner, "Clive Emsley, Hard Men - Violence in England since 1750", Crime, Histoire \& Sociétés / Crime, History \& Societies [Online], Vol. 15, n² | 2011, Online since 08 March 2013, connection on 23 March 2022. URL: http://journals.openedition.org/chs/1310 ; DOI: https://doi.org/10.4000/chs.1310

This text was automatically generated on 23 March 2022.

(C) Droz 


\title{
Clive Emsley, Hard Men - Violence in England since 1750 \\ London, Hambledon and London, 2005, ISBN 1-85285-408-1.
}

\author{
Manuel Eisner
}

\section{REFERENCES}

Clive Emsley, Hard Men - Violence in England since 1750, London, Hambledon and London, 2005, ISBN 1-85285-408-1.

1 In Violence in England since 1750 Emsley has added another important work to his distinguished series of major publications on the history of policing and crime in England since the mid 18th century. It is an impressive book, written in an elegant and lively style that manages to cover a huge theme in a condensed and accessible way.

2 The book essentially offers a lucid and richly documented account of the changing manifestations and perceptions of violence in English society over the past 250 years that can be read with profit both by specialists and non-specialists. Emsley has chosen an unconventional way to organize his topic. Instead of telling a chronological story the book is organized around themes that highlight different aspects of violence in English society. Each theme is introduced by an exemplary story which serves to introduce the main issues. For example, the book comprises is a condensed chapter on the civilization of sports (chapter 3), an interesting overview of changing attitudes towards domestic violence (chapter 4), a fascinating essay on the cultural dichotomy between continental passions and English restraint and fair play (chapter 5), and two chapters on police violence and the violence of the state, which highlight some interesting contradictions between public perceptions and the underlying realities. This kaleidoscopic approach is supported by a wealth of historical material and fascinating case stories the make the book a joy to read.

3 The main thread that binds the various topics together is Emsley's interest in the culturally transmitted notions of Englishness and masculinity. In a nutshell, the book 
argues that throughout the 18th and 19th centuries a cultural imagery of Englishness was constructed that emphasized self-control, respectability and restraint, with the true Englishman using violence only in the last resort, and even then being bound by noble rules of fairness. But, importantly, Emsley demonstrates throughout the book that this stylized imagery was only partly matched by the realities of violence in English society, and that class had a mayor impact on notions of decency, masculinity, and violence throughout the period covered in the book. In contrast, the book is somewhat less interested what one might broadly describe as the "causes" of violence. In particular, those who are interested in how class, age, gender, ethnicity, occupation, education or region may - or may not - have had an impact on changing patterns of violence will find little that answers their questions.

Probably the biggest gap in the book is the less convincing treatment of the changes that occurred since the late 1950s. Arguably the change from a nation that saw itself as the model of a civilized, disciplined, chivalrous, and self-restrained society to one that perceives itself as continuously ridden by violence, binge-drinking, drugs, and antisocial behaviour constitutes a major tidal shift in England's cultural and social fabric. Variously expressing his skepticism of official crime statistics, Emsley remains highly ambivalent about whether any factual change in levels of violence did occur - and what its causes may have been. Having argued, throughout much of the book, that the cultural ideal of self-restraint and civilized behaviour contributed significantly to the decline in violence during 19th and early 20th centuries, it would seem logical to systematically examine whether the decline of these ideals was involved in the increase of violence since the 1950s. Emsley hints at this possibility in the concluding sentences of the book, but he seems reluctant to give it the same.

Overall, this is an excellent original contribution to research on the history of violence and an authoritative overview over a huge topic that deserves a wide readership.

\section{AUTHORS}

\section{MANUEL EISNER}

University of Cambridge

mpe23@cam.ac.uk 